\title{
Застосування магнієвмісних мінералів у лікуванні післяопераційних ранових ускладнень у хворих похилого віку
}

\begin{abstract}
Мета роботи: дослідження протизапальної дії бішофіту при його місцевому застосуванні та його вплив на процеси загоєння післяопераційних ран, у тому числі при ранових ускладненнях.

Матеріали і методи. На клінічному матеріалі, що включає 57 хворих, старших 60 років, яким було виконано впродовж трьох років різні оперативні втручання з приводу хірургічних захворювань черевної порожнини та черевної стінки. Показано в динаміці впродовж місяця безпосередні результати лікування ранових ускладнень (серома, гематома, запальний інфільтрат) із застосуванням бішофіту. В роботі використовували клініко-лабораторні, інструментальні, мікробіологічні та цитологічні методи обстеження хворих.

Результати досліджень та їх обговорення. Доведено, приймання вказаного лікарського препарату сприяє зменшенню ексудації в рані, більш швидкому послабленню інтенсивності болю та зниженню концентрації мікроорганізмів у рані, які підтверджені клініко-лабораторними, цитологічними та інструментальними дослідженнями. Метод можна використовувати разом із класичними способами лікування післяопераційних ран та їх ускладнень. Робота має перспективи щодо подальшого вивчення впливу бішофіту на організм при патологічних станах.
\end{abstract}

Ключові слова: післяопераційні ранові ускладнення; бішофіт; хворі похилого віку; місцеве лікування.

Постановка проблеми і аналіз останніх досліджень та публікацій. У післяопераційному періоді часто спостерігаються різні ранові ускладнення, частота яких може досягати, за даними різних авторів, 20,9-49,2 \% [2-7]. Відсутність єдиної доктрини лікування геріатрічних хворих зумовлює високу післяопераційну летальність і значну кількість післяопераційних ускладнень [8-10]. I до сьогодні проблема ранових післяопераційних ускладнень у даної групи хворих залишається актуальною.

Одним із ефективних засобів комплексної місцевої терапії $є$ магнієвмісний мінерал бішофіт. Загальновідомо, що бішофіт має протизапальні властивості. Також було відкрито властивість бішофіту пригнічувати ріст і розмноження патогенної та умовно-патогенної мікрофлори. Поряд із цим є сучасні свідчення, що бішофіт збільшує фагоцитарну активність моноцитів, макрофагів та нейтрофілів макроорганізму. Але комплексних робіт, присвячених обгрунтуванню місцевого застосування бішофіту при ранових ускладненнях в осіб похилого віку, з урахуванням клініко-функціональних результатів недостатньо.

Мета роботи: дослідити протизапальні властивості бішофіту при його місцевому застосуванні та роль у загоєнні післяопераційних ран.

Матеріали і методи. У хірургічному відділенні геріатричного профілю КЗ “Дніпропетровське клінічне об’єднання швидкої медичної допомоги ДОР” впродовж трьох років було відібрано 57 хворих, старших 60 років із різними видами ранових ускладнень після операцій на черевній порожнині та передній черевній стінці.

Пацієнти були розподілені на дві групи.

Лікування ранових ускладнень у першій групі включало евакуацію рідинного вмісту ранової порожнини (за наявністю) шляхом пункції або дренування ранової порожнини, а також УВЧ-терапію та накладання вологих пов'язок із декасаном (традиційна методика). Лікування ранових ускладнень у другій групі включало евакуацію вмісту ранової порожнини та накладання вологих пов' язок із препаратом “Бішофіт полтавський”.

Контрольну групу складали 20 пацієнтів, які не мали ранових ускладнень після операцій на черевній порожнині та передній черевній стінці.

Задля оцінки вираженості запальної реакції пацієнтам проводився комплекс загальноклінічних обстежень. Кожному пацієнту проводили термометрію. Біль у ділянці рани визначали за шкалою ВАШ (від 0 до 10 балів), також визначали кількість ексудату (за наявності), отриманого при пункції рани або череж дренажі. Задля вираження інтенсивності запальної реакції визначали ширину зони гіперемії в ділянці рани, рівень лейкоцитів у периферичній крові, ШОЕ, а також показники зсуву лейкоцитарної формули - індекс зсуву лейкоцитів та лейкоцитарний індекс інтоксикації. 


\section{З ДОСВІДУ РОБОТИ}

Для підтвердження клінічних даних проведено ультразвукове обстеження ранової ділянки, мікробіологічні та цитологічні дослідження ранової порожнини. Всі дослідження проведено в 6 етапів: до операції, на 1, 3, 7, 14 та 30 доби після операції.

Результати досліджень та їх обговорення. Показники запалення, які визначали в усіх трьох групах, суттєво не відрізнялися до операції та в першу добу після неї і переважно були в межах норми (табл. 1, 2).

Вихід за межі норми до операції таких показників, як ШОЕ та лейкоцитарний індекс інтоксикації пояснюється наявністю загального запального процесу, який саме і був причиною виконання операції.
За даними таблиці 2, в обох групах спостерігалося мікробне запалення в рані (ширина ранової порожнини більше 13 мм, здебільшого має місце ексудат у рановій порожнині та наявність лейкоцитів при цитологічному дослідженні). При мікробіологічному дослідженні ранової порожнини виявлено наявність стафілококової інфекції (в обох групах виявлено Sthaph. aureus - у першій групі в концентрації $10^{5} \mathrm{KУO} / \mathrm{cm}^{3}$ - в 5 випадках, $10^{6} \mathrm{KУO} / \mathrm{cm}^{3}$ - в 1 випадку, $10^{7} \mathrm{KУO} / \mathrm{cm}^{3}$ - в 1 випадку; в другій групі $10^{4} \mathrm{KУO} / \mathrm{cm}^{3}$ - в 1 випадку, $10^{5} \mathrm{KУO} / \mathrm{cm}^{3}$ - у 3 випадках, $10^{6} \mathrm{KУO} / \mathrm{cm}^{3}$ - в 2 випадках). Також у першій групі у 2 пацієнтів виявлено Moraxella catarrhalis в концентрації $10^{3} \mathrm{KVO} / \mathrm{cm}^{3}-1$ пацієнт та $10^{5} \mathrm{KУO} / \mathrm{cm}^{3}$ - 1 пацієнт, що підтверджує наявність внутрішньогоспітальної флори.

Таблиця 1. Початковий стан показників запалення

\begin{tabular}{||l|c|c|c||}
\hline \multicolumn{1}{|c|}{ Показники } & 1 група & 2 група & 3 група \\
\hline Температура тіла, ${ }^{\circ} \mathrm{C}$ & $36,65 \pm 0,03$ & $36,67 \pm 0,03$ & $36,70 \pm 0,07$ \\
\hline Кількість лейкоцитів, $10^{9} / л$ & $6,07 \pm 0,34$ & $6,82 \pm 0,37$ & $6,96 \pm 0,65$ \\
\hline Індекс зсуву лейкоцитів & $0,026 \pm 0,004$ & $0,03 \pm 0,003$ & $0,033 \pm 0,005$ \\
\hline Лейкоцитарний індекс інтоксикації & $1,08 \pm 0,13$ & $0,95 \pm 0,09$ & $1,04 \pm 0,16$ \\
\hline ШОЕ, мм/год & $10,65 \pm 1,238$ & $6,577 \pm 0,4194$ & $9,5 \pm 1,09$ \\
\hline \hline
\end{tabular}

Таблиця 2. Стан показників запалення на першу добу після операції

\begin{tabular}{|c|c|c|c|}
\hline Показники & 1 група & 2 група & 3 група \\
\hline Температура тіла, ${ }^{\circ} \mathrm{C}$ & $37,31 \pm 0,1$ & $37,22 \pm 0,03$ & $37,09 \pm 0,1$ \\
\hline Біль у ділянці рани за ВАШ & $8 \pm 0,18$ & $7,38 \pm 0,27$ & $7,05 \pm 0,29$ \\
\hline Кількість ексудату, мл & $39,35 \pm 5,42$ & $28,19 \pm 4,19$ & 0 \\
\hline Ширина зони гіперемії в ділянці рани, мм & $7,58 \pm 0,36$ & $5,92 \pm 0,73$ & 0 \\
\hline Кількість лейкоцитів, $10^{9} / л$ & $8,1 \pm 0,4$ & $6,44 \pm 0,39$ & $7,67 \pm 0,55$ \\
\hline Індекс зсуву лейкоцитів & $0,04 \pm 0,006$ & $0,03 \pm 0,004$ & $0,04 \pm 0,008$ \\
\hline Лейкоцитарний індекс інтоксикації & $1,1 \pm 0,09$ & $0,97 \pm 0,09$ & $0,65 \pm 0,09$ \\
\hline ШОЕ, мм/год & $18,13 \pm 1,9$ & $10,54 \pm 0,78$ & $16,7 \pm 1,93$ \\
\hline Ширина ранової порожнини за даними УЗД, мм & $18,56 \pm 2,073$ & $17,72 \pm 2,525$ & 0 \\
\hline Об’єм ранової порожнини за даними УЗД, см³ & $42,23 \pm 6,83$ & $29,15 \pm 4,13$ & 0 \\
\hline $\begin{array}{l}\text { Наявність рідини в рановій порожнині за даними УЗД, } \\
\text { кількість випадків, \% }\end{array}$ & $26(83,87 \%)$ & $23(88,46 \%)$ & 0 \\
\hline $\begin{array}{l}\text { Цитологічне обстеження ранової порожнини (кількість } \\
\text { лейкоцитів у полі зору) }\end{array}$ & $16,39 \pm 2,545$ & $12,2 \pm 2,007$ & 0 \\
\hline
\end{tabular}


Після початку лікування ранових ускладнень у хворих другої групи відносно першої вже на третю добу помітно зниження інтенсивності болю на 31,7 \% (р>0,95), кількості ексудату на 84,6 \% (p>0,95), ширини зони гіперемії на 32,9 \% (p>0,95), лейкоцитозу на 20,5 \% (p>0,95) (табл. 3).

Помітне зменшення ширини ранової порожнини на 41,41 \% у другій групі порівняно 3 першою (p>0,95), об’єму ранової порожнини на 82,77 \% $(\mathrm{p}>0,95)$ та кількості лейкоцитів при цитологічному дослідженні на 64,76 \% (р>0,95).

При мікробіологічному дослідженні ранової порожнини в першій групі спостерігається наявність Staphylococcus aureus в концентрації $10^{3} \mathrm{KУO} / \mathrm{cm}^{3}$ - у 2 випадках, $10^{4} \mathrm{KУO} / \mathrm{cm}^{3}$ - в 1 випадку та $10^{5} \mathrm{KУO} / \mathrm{cm}^{3}$ - у 2 випадках, Moraxella catarrhalis $10^{3} \mathrm{KУO} / \mathrm{cm}^{3}$ - в 1 випадку; у другій групі - Sthaph. aureus $10^{2} \mathrm{KVO} / \mathrm{cm}^{3}-$ в 1 випадку, $10^{4} \mathrm{KУO} / \mathrm{cm}^{3}$ - в 1 випадку, $10^{5} \mathrm{KУO} / \mathrm{cm}^{3}-$ в 1 випадку та $10^{6} \mathrm{KУO} / \mathrm{cm}^{3}$ - в 1 випадку.

На 7 добу помітна різниця інтенсивності болю в ділянці рани (на 60,8 \%) та кількість ексудату (на 72,8 \%) у хворих другої групи порівняно 3 хворими першої (табл. 4). Тоді як показники периферичної крові, окрім ШОЕ, достовірно не відрізняються в усіх трьох групах. Помітна різниця ширини ранової порожнини на 62,88 \% (p>0,95), об’єму ранової порожнини на 85,76 \% $(\mathrm{p}>0,95)$ у хворих другої групи порівняно $з$ хворими першої. Також значно менша кількість випадків виявлення ексудату в рановій порожнині. Цитологічне дослідження пацієнтів другої групі не виявило клітин запалення.

При мікробіологічному дослідженні у пацієнтів першої групи виявлений Sthaph. aureus в концентрації $10^{3} \mathrm{KУO} / \mathrm{cm}^{3}$ - в 2 випадках та $10^{5} \mathrm{KYO} / \mathrm{cm}^{3}$ - в 1 випадку, а також Moraxella catarrhalis в концентрації $10^{2} \mathrm{KVO} / \mathrm{cm}^{3}$ - в 1 випадку. Тоді як у пацієнтів 2 групи росту мікрофлори не виявлено взагалі.

Ексудація з рани у хворих другої групи закінчується повністю на 14 добу, тоді як у хворих 1 групи на цей момент залишається незначна кількість ексудату. Показники периферичної крові, окрім ШОЕ, на цей час знову достовірно не відрізняються в усіх групах (табл. 5). У частини пацієнтів першої групи на 14 добу після операції ще спостерігається залишкова ранова порожнина, тоді як у всіх пацієнтів другої групи ранова порожнина повністю закрилась. При мікробіологічному дослідженні в 1 пацієнта першої групи спостерігається наявність Staphylococcus aureus в концентрації $10^{3} \mathrm{KVO} / \mathrm{cm}^{3}$.

Через місяць після операції всі вимірювальні показники догсягли норми, ексудація повністю припинилась у всіх хворих (табл. 6). Наявність ранової порожнини не спостерігали у всіх хворих.

Таблиця 3. Стан показників запалення на 3 добу після операції

\begin{tabular}{||l|c|c|c||}
\hline \multicolumn{1}{|c|}{ Показники } & 1 група & 2 група & 3 група \\
\hline Температура тіла, ${ }^{\circ} \mathrm{C}$ & $37,1 \pm 0,07$ & $36,99 \pm 0,19$ & $36,95 \pm 0,09$ \\
\hline Біль у ділянці рани за ВАШ & $6,19 \pm 0,22$ & $4,23 \pm 0,27$ & $3,1 \pm 0,32$ \\
\hline Кількість ексудату, мл & $56,13 \pm 11,25$ & $8,65 \pm 1,2$ & 0 \\
\hline Ширина зони гіперемії в ділянці рани, мм & $5,39 \pm 0,34$ & $3,62 \pm 0,27$ & 0 \\
\hline Кількість лейкоцитів, 109/л & $7,89 \pm 0,41$ & $7,1 \pm 0,65$ & $7,80 \pm 0,63$ \\
\hline Індекс зсуву лейкоцитів & $0,045 \pm 0,007$ & $0,05 \pm 0,01$ & $0,05 \pm 0,01$ \\
\hline Лейкоцитарний індекс інтоксикації & $2,51 \pm 0,53$ & $1,52 \pm 0,36$ & $2,52 \pm 0,77$ \\
\hline ШОЕ, мм/год & $24,58 \pm 2,40$ & $21,08 \pm 3,34$ & $18,90 \pm 2,89$ \\
\hline Ширина ранової порожнини за даними УзД, мм & $13.95 \pm 1,529$ & $8,173 \pm 1,137$ & 0 \\
\hline Об’єм ранової порожнини за даними УзД, см ${ }^{3}$ & $26,59 \pm 4,245$ & $4,582 \pm 0,7186$ & 0 \\
\hline $\begin{array}{l}\text { Наявність рідини в рановій порожнині за даними УЗД, } \\
\text { кількість випадків, \% }\end{array}$ & 27 & 23 & 0 \\
\hline $\begin{array}{l}\text { Цитологічне обстеження ранової порожнини (кількість } \\
\text { лейкоцитів у полі зору) }\end{array}$ & $14,87 \pm 1,686$ & $5,24 \pm 0,7506$ & 0 \\
\hline \hline
\end{tabular}


Таблиця 4. Стан показників запалення на 7 добу після операції

\begin{tabular}{|c|c|c|c|}
\hline Показники & 1 група & 2 група & 3 група \\
\hline Температура тіла, ${ }^{\circ} \mathrm{C}$ & $36,68 \pm 0,04$ & $36,6 \pm 0,04$ & $36,69 \pm 0,04$ \\
\hline Біль у ділянці рани за ВАШ & $4,81 \pm 0,29$ & $1,89 \pm 0,27$ & $1,60 \pm 0,23$ \\
\hline Кількість ексудату, мл & $12,41 \pm 4,57$ & $3,38 \pm 0,27$ & 0 \\
\hline Ширина зони гіперемії в ділянці рани, мм & $3,42 \pm 0,45$ & $3,38 \pm 0,33$ & 0 \\
\hline Кількість лейкоцитів, $10^{9} / л$ & $7,27 \pm 0,46$ & $6,33 \pm 0,25$ & $5,99 \pm 0,4$ \\
\hline Індекс зсуву лейкоцитів & $0,027 \pm 0,003$ & $0,03 \pm 0,003$ & $0,036 \pm 0,006$ \\
\hline Лейкоцитарний індекс інтоксикації & $0,93 \pm 0,11$ & $0,77 \pm 0,07$ & $0,71 \pm 0,08$ \\
\hline ШОЕ, мм/год & $18,90 \pm 1,82$ & $10,92 \pm 1,04$ & $10,2 \pm 0,87$ \\
\hline Ширина ранової порожнини за даними УЗД, мм & $6.829 \pm 1,21$ & $2,535 \pm 0,3928$ & 0 \\
\hline Об’єм ранової порожнини за даними УзД, см³ & $12,08 \pm 3,192$ & $1,72 \pm 0,2469$ & 0 \\
\hline $\begin{array}{l}\text { Наявність рідини в рановій порожнині за даними } \\
\text { УЗД, кількість випадків, \% }\end{array}$ & $\begin{array}{c}19 \\
(61,29 \%)\end{array}$ & $\begin{array}{c}6 \\
(23,08 \%)\end{array}$ & 0 \\
\hline $\begin{array}{l}\text { Цитологічне обстеження ранової порожнини (кіль- } \\
\text { кість лейкоцитів у полі зору) }\end{array}$ & $5,565 \pm 1,095$ & 0 & 0 \\
\hline
\end{tabular}

Таблиця 5. Стан показників запалення на 14 добу після операції

\begin{tabular}{|c|c|c|c|}
\hline Показники & 1 група & 2 група & 3 група \\
\hline Температура тіла, ${ }^{\circ} \mathrm{C}$ & $36,54 \pm 0,04$ & $36,53 \pm 0,04$ & $36,58 \pm 0,05$ \\
\hline Біль у ділянці рани за ВАШ & $1,47 \pm 0,13$ & $2,42 \pm 0,13$ & $2,1 \pm 0,28$ \\
\hline Кількість ексудату, мл & $2,97 \pm 1,92$ & 0 & 0 \\
\hline Ширина зоні гіперемії в ділянці рани, мм & $0,59 \pm 0,21$ & 0 & 0 \\
\hline Кількість лейкоцитів, $10^{9} /$ л & $5,71 \pm 0,22$ & $5,78 \pm 0,25$ & $4,62 \pm 0,2$ \\
\hline Індекс зсуву лейкоцитів & $0,033 \pm 0,003$ & $0,034 \pm 0,002$ & $0,043 \pm 0,003$ \\
\hline Лейкоцитарний індекс інтоксикації & $0,70 \pm 0,05$ & $0,71 \pm 0,04$ & $0,70 \pm 0,08$ \\
\hline ШОЕ, мм/год & $11,45 \pm 0,75$ & $9,23 \pm 0,63$ & $8,85 \pm 0,61$ \\
\hline Ширина ранової порожнини за даними УЗД, мм & $1.42 \pm 0,81$ & 0 & 0 \\
\hline Об’єм ранової порожнини за даними УЗД, см³ & $3.58 \pm 2,43$ & 0 & 0 \\
\hline $\begin{array}{l}\text { Наявність рідини в рановій порожнині за даними УЗД, } \\
\text { кількість випадків, \% }\end{array}$ & $\begin{array}{c}5 \\
(16,13 \%)\end{array}$ & 0 & 0 \\
\hline $\begin{array}{l}\text { Цитологічне обстеження ранової порожнини (кіль- } \\
\text { кість лейкоцитів у полі зору) }\end{array}$ & 0 & 0 & 0 \\
\hline
\end{tabular}


Таблиця 6. Стан показників запалення на 30 добу після операції

\begin{tabular}{||l|c|c|c||}
\hline \multicolumn{1}{|c|}{ Показники } & 1 група & 2 група & 3 група \\
\hline Температура тіла, ${ }^{\circ} \mathrm{C}$ & $36,49 \pm 0,03$ & $36,49 \pm 0,03$ & $36,51 \pm 0,03$ \\
\hline Біль у ділянці рани за ВАШ & 0 & 0 & 0 \\
\hline Кількість ексудату, мл & 0 & 0 & 0 \\
\hline Ширина зони гіперемії в ділянці рани, мм & 0 & 0 & 0 \\
\hline Кількість лейкоцитів, $10^{9} / л$ & $5,303 \pm 0,18$ & $5,52 \pm 0,25$ & $4,71 \pm 0,19$ \\
\hline Індекс зсуву лейкоцитів & $0,03 \pm 0,003$ & $0,03 \pm 0,003$ & $0,037 \pm 0,003$ \\
\hline Лейкоцитарний індекс інтоксикації & $0,62 \pm 0,03$ & $0,56 \pm 0,02$ & $0,63 \pm 0,02$ \\
\hline ШОЕ, мм/год & $8,48 \pm 0,38$ & $7,23 \pm 0,52$ & $7,25 \pm 0,49$ \\
\hline
\end{tabular}

Висновки. Таким чином, використання бішофіту в лікуванні таких післяопераційних ранових ускладнень, як гематома, серома та запальний інфільтрат у вигляді компресів приводить до суттєвого зменшення ексудації в рані, швидкого зниження інтенсивності болю та концентрації мікрофлори в рані, що відчутно покращує загальний стан пацієнтів, сприяє скороченню термінів загоєння ран та одужання пацієнтів в цілому. Загальнозапальна реакція організму в пацієнтів згідно

\section{СПИСОК ЛІТЕРАТУРИ}

1. Морган-мл. Дж. Э. Клиническая анестезиология. - 3-е издание. / Дж. Э. Морган-мл., С. М. Мегид. - М., 2004. С. $171-176$.

2. Баязитов М. Р. Ефективність алопластики великих та гігантських післяопераційних вентральних гриж : автореф. дис. ... канд. мед. наук. / М. Р. Баязитов. - Тернопіль, 2001.

3. Жебровский В. В. Осложнения заживления раны после операции по поводу грыжи живота и их профилактика / В. В. Жебровский, Ф. Н. Ильченко, М. М. Салем // Клін. хірургія. - 1999. - № 12. - С. 26-28.

4. Ткаченко А. Е. Реконструктивная абдоминопластика в хирургической реабилитации больных с вентральными грыжами: автореф. дисс. ... канд. мед. наук / А. Е. Ткаченко. - Екатеринбург, 1999.

5. Ткаченко А. Н. Прогноз и профилактика гнойных осложнений при лечении послеоперационных вентральных грыж : автореф. дисс. ... канд. мед. наук / А. Н. Ткаченко. - СПб.,1999.

\section{REFERENCES}

1. Morgan-ml, Dzh. E., \& Megid, S.M. (2004). Klinicheskaya anesteziologiya [Clinical anesthesiology]. 3rd Ed. Moscow [in Russian].

2. Bayazytov, M.R. (2001). Efektyvnist aloplastyky velykykh ta hihantskykh pisliaoperatsiinykh ventralnykh hryzh [Efficacy of з показниками термометрії та клінічного аналізу крові суттєво не відрізняється від такої при використанні класичних методів лікування ран.

Перспективи подальших досліджень. Проведені дослідження мають перспективи в сенсі подальшого аналізу впливу бішофіту не тільки на показники місцевого запалення тканин, але й на показники імунореактивності організму, деякі біохімічні та біофізичні властивості, структурний профіль тканин шкіри та інші.

6. Chevrel J. P. Polyester mesh for incisional hernia repair / J. P. Chevrel, A. M. Rath / In: Incisional hernia, Schumpelick V., Kingsnorth A. N., eds. - Berlin-Heidelberg: Springer-Verlag, 1999. - P. 327-330.

7. White T. J. Factors affecting wound complications in repair of ventral hernias / T. J. White, M. C. Santos, J. S. Thompson // Amer. J. Surg. - 1998. - Vol. 64 (3). - P. 276-280.

8. Патогенез и хирургическое лечение послеоперационных вентральных грыж / [В. И. Белоконев, Т. А. Федорина, 3. В. Ковалева и др.]. - СПб., 2005. - 208 с.

9. Kingsnorth A. K. LeBlanc Hernias: inguinal and incisional / A. K. Kingsnorth // Lancet. - 2003. - Vol. 362 (8). - P. 1561-1571. 10. Created risk of incisional hernia with morbidly obese than steroid-dependent patients and low recurrence with prefascial polypropilene mesh / H. J. Sugerman, J. M. Kellum Jr, H. D. Reines [et al.] // Amer. J. Surg. - 1996. - Vol. 171 (1). - P. $80-84$. 


\section{З ДОСВІДУ РОБОТИ}

surgery for abdominal hernia and their prevention]. Klinichna khirurgiia - Clinical Surgery, 12, 26-28 [in Russian].

4. Tkachenko, A.Ye. (1999). Rekonstruktivnaya abdominoplastika v khirurgicheskoy reabilitatsii bolnykh s ventralnymi gryzhami [Reconstructive abdominoplasty in the surgical rehabilitation of patients with ventral hernias]. Candidate's thesis. Yekaterinburg [in Russian].

5. Tkachenko, A.N. (1999). Prognoz i profilaktika gnoynykh oslozhneniy pri lechenii posleoperatsionnykh ventralnykh gryzh [Prediction and prevention of purulent complications in the treatment of postoperative ventral hernias]. Candidate's thesis. Saint-Petersburg [in Russian].

6. Chevrel, J.P., \& Rath, A.M. (1999). Polyester mesh for incisional hernia repair. In: Incisional hernia, Schumpelick V., Kingsnorth A. N., eds. Berlin-Heidelberg: Springer-Verlag.
7. White, T.J., Santos, M.C., \& Thompson, J.S. (1998). Factors affecting wound complications in repair of ventral hernias. Amer. J. Surg., 64 (3), 276-280.

8. Belokonev, V.I., Fedorina, T.A., Kovaleva, Z.V., Pushkin, S. Yu., Nagapetyan, S.V., \& Supilnikov, A.A. (2005). Patogenez i khirurgicheskoye lecheniye posleoperatsionnykh ventralnykh gryzh [Pathogenesis and surgical treatment of postoperative ventral hernias]. Saint-Petersburg [in Russian].

9. Kingsnorth, A.K. (2003). LeBlanc Hernias: inguinal and incisional. Lancet, 362 (8), 1561-1571.

10. Sugerman, H.J., Kellum, J.M. Jr, Reines, H.D., DeMaria, E.J., Newsome, H.H., \& Lowry, J.W. (1996). Created risk of incisional hernia with morbidly obese than steroid-dependent patients and low recurrence with prefascial polypropilene mesh. Amer. J. Surg., 171 (1), 80-84.

\section{THE ADMINISTRATION OF MAGNESIUM-CONTAINING REMEDY FOR POSTOPERATIVE WOUND COMPLICATIONS TREATMENT IN ELDERLY PATIENTS}

The aim of the work: to analyze anti-inflammatory action of bishofite local administration and its influence to wounds healing and after surgery complications in particular.

Materials and Methods. Our research includes 57 patients above 60 years old, who underwent various surgical interventions on the abdomen cavity and wall during three years. There was observed in dynamics during one month short-term results of wound curing (seroma, hematoma, infiltrate) using locally applications of bishofite. The presented data confirmed by complex of clinico-laboratory, cytological, instrumental methods of examination.

Results and Discussion. The presented research revealed the positive results connected with bishofite implementation in wounds treatment such as abatement of pain, decreasing exudate amount and numerous of microorganisms in wound. On the base of clinics and laboratory tests along with ultrasonic images we found an evidence of bishofite efficiency at local treating of wounds. This method could be using beside classic and trivial ones in general surgery and in wounds curing after surgery in particular.

The furthermore research would have been a perspective in immunological and pathomorphological examinations not only locally but to the whole body in different group of patients.

Key words: postoperative wound complications; bishofite; elderly patients; local treatment. 